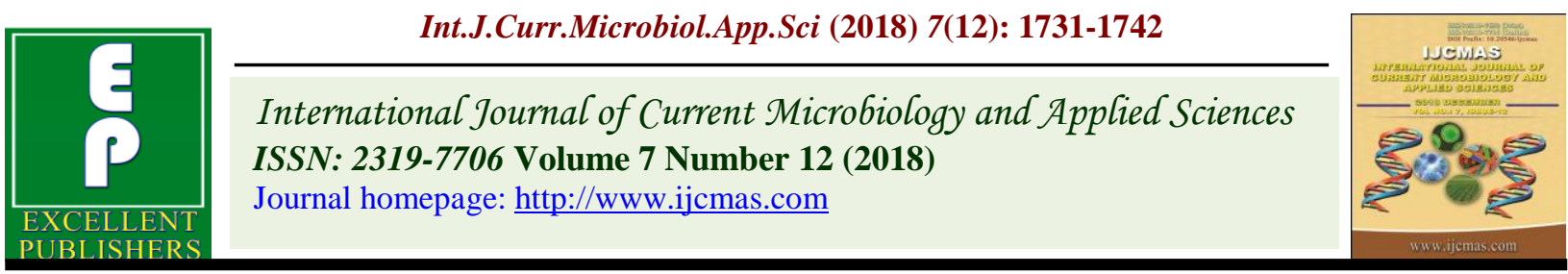

Original Research Article

https://doi.org/10.20546/ijcmas.2018.712.201

\title{
Ornamental Germplasm: Potential New Resources for Floriculture Industry
}

\author{
Anitha Pedapati*, Satish Kumar Yadav, Vandana Tyagi, S.P. Singh, \\ S.S. Ranga, P.C. Binda and Pratibha Brahmi
}

ICAR-National Bureau of Plant Genetic Resources, New Delhi-110012, India

*Corresponding author

\section{A B S T R A C T}

\begin{abstract}
Conservation of ornamental crops is the foundation to protect the valuable native and wild relatives of ornamental germplasm to secure the future needs of researchers and breeders. This paper analyses the floriculture wealth of PGR and also their availability to breeders for the major ornamental crops germplasm available across globe. The available number of accessions held in the different genebanks located globally would help breeders for further introduction and utilization in ornamental crops varietal development programmes. The ornamental crops research was carried out by utilizing large diversity in germplasm available indigenously and imported through NBPGR. More than 1293 new accessions of diverse ornamental crops were acquired since last three decades (1982-2016). Majority of the accessions introduced were from USA (55\%) followed by UK (9\%), Slovenia (6\%) and the Netherlands (5\%). ICAR-NBPGR also registered 38 accessions of rose, gerbera, jasmine, anthuriums, carnations, china aster, gladiolus, orchids, chrysanthemums and crossandra. Search of new genetic sources from the already collected and conserved germplasm is greatly appreciated with reference to the utilization of germplasm in breeding programmes. The genotypes developed with significant promising traits from the valuable conserved germplasm play a major role in the varietal development. Native genetic resources provide less variability consequently introduction of genetic resources to diversify the yield, color and size of ornamental plants is a priority.
\end{abstract}

Keywords

Accessions, germplasm, Ornamental crops, Utilization

Article Info

Accepted: 12 November 2018 Available Online: 10 December 2018

\section{Introduction}

India is enriched with diverse agro-climatic conditions such as fertile land, suitable climate, abundant water supply, low labour cost, availability of skilled manpower, etc. which are quite beneficial for growing a variety of flowering plants throughout the year. Globally major emphasis has been given to floriculture sector due to its tremendous opportunities in the present scenario. Various uses like employment generation, higher returns per unit area and fulfilling the delightful aesthetic persuits of the people it also facilitates to earn foreign exchange. Production and marketing of ornamental crops contribute to national GDP of many countries and thus can play a significant secondary role in enhancing food security and nutrition (Jaenicke, 2013). More specifically, they are being used as raw materials in the manufacture of essence, perfumes, medicines 
and confectioneries for direct consumption by the society. India has a scope to bridge the gap between demand and supply as global demand of floricultural products is growing at a faster rate. According to International Association of Horticultural Producers (AIPH, 2016) a total 650,000 hectares area was under flower production globally with production value of 35,000 million EUR. India occupied a floriculture area of 183,000 ha, which was $26 \%$ of the global area according to Indian Horticulture data base.(Indian Horticultural data base, 2015).

The native ornamental species of India are orchids, musk rose, lotus, water lily, crossandra, clerodendron, tabernamontana, begonia, clitoria and clematis. India with its varied climatic zones is ideally suited for growing several types of flowers in different seasons. In recent times, new flowers like iris, curcuma, liatris etc have been introduced as an ornamental germplasm. The conventional method the introduction of germplasm is the recommended in specific regions is often used in ornamental plant breeding (Flavia et al., 2015). Globally, plant germplasm conservation effort is continually focused do not have food and industrial crops. International agencies including IPGRI and FAO have no mandate to conserve ornamental crops. Ornamental plants genetic resources are conserved mainly in botanical gardens, Arborata, private collection of seed companies and plant nurseries. Very few national gene banks conserve some herbaceous ornamental plants in their collections including Royal Botanical Garden, Kew and Ornamental Plant Germplasm Centre (OPGC), Ohio State University, USA.

Identifying and evaluating useful genetic traits desired by the commercial industries and consumers creates a need to collect and conserve a wide range of species in order to capture greater genetic diversity. Despite the large diversity of floricultural crops present in the market, many of these crops have been developed from a narrow germplasm base (Boyle 1991). Plant breeders' success would be deficient without availability of diverse germplasm for researchers to develop improved ornamental varieties. Plant germplasm conservation is the safe keeping of the genetic diversity of targeted crops and their related species, as seeds or living plants for future use. A typical germplasm conservation program includes activities in plant exploration, plant conservation, evaluation, documentation and distribution.

\section{Materials and Methods}

Information related to global ornamental crops was collected from the official website of the International Association of Horticultural Producers (AIPH, 2016). The data related to ornamentals collected from US National Plant Germplasm System (NPGS) and EURISCO database and relevant reports of various institutions and organizations were analysed. The mandate of germplasm exchange unit of ICAR- National Bureau of Plant Genetic Resources (NBPGR) acquisition of germplasm for the benefit of researchers and users, with in the country and internationally. ICARNBPGR is the nodal agency for introduction and facilitating import of germplasm for research purposes from different countries. The literature screening of global databases, journals, catalogues, periodicals and research reports of various institutes was done for identifying the promising traits which are suitable to Indian conditions. The Director, ICAR-NBPGR is authorized to issue import permit as per the Plant Quarantine Regulations of Import into India, order 2003 and receive imported materials from custom authorities for its quarantine inspection and healthy samples are allotted the national identity number (Exotic collection- EC number). These accessions were utilized in various crop 
improvements and breeding programs (Anitha et al., 2014). The crop germplasm were received in the form of seed/bulbs/cuttings (perishable material) and therefore utmost care is being taken in the handling of the material. The material was provided to the National Active Germplasm Site (NAGS) for its establishment and maintenance (Yadav et al., 2014).

\section{Results and Discussion}

This data was collected from the Indian horticultural data base and other relevant reports of Indian agriculture. Among the commercial flowers cultivation in India (Fig. 1), marigold occupies maximum area (56.04 thousand hectare) and production (497.59 thousand metric tons) followed by rose (26.33 thousand hectare and 212.7 thousand metric tons) and chrysanthemum (11.05 thousand hectare and 112.79 thousand metric tons) (Source: Indiastat). Figure 2 shows the major countries from which India importing floricultural products for commercial use during the period 2015-16. India imported 339.76 MT of commercial flowers worth of 1.3 USD million from the other countries. It was observed that majority of the commercial flowers import to India were from Thailand (166.28 MT) followed by The Netherlands (65.96 MT) and China (22.22 MT).The strengths of Indian flower sector include favourable soil, geographical conditions, environment and labour cost. In order to reduce the imports from other countries there is a need to develop indigenous technologies in modern floriculture. To meet the growing needs of national and international markets there is a need to shift non-traditional cultivating areas to grow ornamental plants.

\section{Status of introduced ornamental germplasm}

Germplasm collections were acquired with an aim to ameliorate narrow genetic base and produce superior hybrid seeds suitable to different agro-climatic conditions of identified areas (Pedapati et al., 2013). An enormous amount of ornamental germplasm had been collected from different countries in the past three decades for enriching our agro biodiversity. More than 1293 new accessions of diverse ornamental crops were acquired in last 35 years (1982-2016) and assigned Exotic collection numbers (EC) for further use. The figure 3 depicts the majority of the accessions introduced from USA (55\%) followed by UK (9\%), Slovenia (6\%) and Netherlands (5\%). Among the introduced germplasm, the number of accessions introduced mostly of rose (33\%) followed by marigold (17\%), and gladiolus $(12 \%)$. Figure 4 shows the trend of introduced ornamental germplasm through ICARNBPGR for research purpose. From these data it is clear that ornamental germplasm introduction tremendously progressed till 2012-13.

Some important promising introductions were, a Russian origin wild Chrysanthemum zawadskii subsp. latilobum (EC733384), Chrysanthemum morifolium (EC461856) from Israel; wild rose species from the Netherlands (EC308404), USA (EC267829, UK (EC160021), Denmark (EC165966), Canada (EC417008); improved carnation cultivars like extra dwarf mixed (EC733476), arctic fire (EC733475) from USA, JH-16-82 (EC733482) originated from Japan and Russian originated wild species Dianthus superbus (EC733483) were introduced recently in carnations. At present scenario the demand of commercial flowers is high due to their high commercial value and also shifting of traditional flowers to cut flower cultivation. Majority of the ornamental germplasm in India are maintained by the Directorate of floriculture research (DFR), ICAR-Indian Institute of Horticultural Research (IIHR), ICAR-Indian Agricultural Research Institute (IARI), National Botanical Research Institute (NBRI), ICAR-NBPGR, National Research 
Centre for Orchids, and AICRP on floriculture sub stations located in different locations in India.

\section{Registered ornamental germplasm}

The registration of ornamental germplasm is not as much as for other food crops. However, so far 38 accessions of ornamental crops including rose, gerbera, jasmine, anthuriums, carnations, china aster, gladiolus, orchids, chrysanthemums and crossandra have been registered by ICAR-NBPGR (Table 1). As per the details of NBPGR Inventory of Registered Crop Germplasm (2016) the novel traits which were registered are notably medium to standard size flowers $(\sim 8-10 \mathrm{~cm}$ flower diameter), White flower colour and Yellow orange flower color of gerbera. Gladiolus hybrids registered are IC296733 (spike length$138 \mathrm{~cm}$, number of florets-18.5 and flower diameter- $10.2 \mathrm{~cm}$ ), IC296774 (spike length$115 \mathrm{~cm}$, number of florest-18.3 and flower diameter-11.8 cm), IC296775 (spike length$125.4 \mathrm{~cm}$, number of florets-17.1 and flowers $10.5 \mathrm{~cm}$ in diameter), IC0611879 (Spike length- $93 \mathrm{~cm}$ with more than 16 florets and at a time 5-6 floretes remain open on the spike) and IC0611878 (Number of florets-18.44 and spikes length is more than $100 \mathrm{~cm}$ ). Many varieties developed by public and private sector's therefore, a need to register more by the public sectors and encourage farmers to register their varieties.

\section{Utilization of ornamental germplasm}

Ornamental plants genetic resources are more often utilized by private and commercial seed companies and released commercial varieties (Heywood, 2003 and Tay, 2007). There are numerous examples of ornamental genetic resources utilization in varietal development programme in India. From the last three decades tremendously increased the development of commercial flower varieties.
Under utilization programmes breeders developed and released various new and attractive varieties with improved traits, including new and multi colors, altered forms, enhanced fragrance and increased flower longevity. The genetic improvement and management of ornamental genetic resources was started in IARI, NBRI, IIHR and later this work streamlined with the establishment of DFR and AICRP floriculture. Many more significant achievements were made by the researchers/breeders in developing new varieties of different ornamental crops with superior promising traits. Among the commercial flowers rose occupies utmost importance, as a result more than 600 varieties have been developed with attractive flower colour, form and fragrance, floriferousness, resistance to pests and diseases and suitability for growing under our varied agro-climatic conditions. The gladiolus breeding work was carried out at the IARI and Regional Station at Katrain, IIHR, NBRI on the development of varieties with attractive colour and large size of florists mainly for cut-flowers, long spikes, more number of well spaced and large-sized florists, good corm multiplication ability and resistance to Fusarium wilt. Chrysanthemum varieties suitable for exhibition, cut-flowers and garland are developed by NBRI and IARI a new approach was also adopted to breed varieties which naturally bloom in different months without light and temperature control. Commercial cultivation is in infancy while carnation is an important cut-flower cross flower trade. Mutation breeding experiments of different lines resulted in some interesting mutants with variegated leaf. More than 150 varieties of bougainvillea were developed through hybridization and mutation breeding. Besides very promising, colourful and floriferous hybrids were developed which are ideal and handy for pot culture. Blotched-bract varieties like Begum Sikandar, Wajid Ali Shah and Mary Palmer Special are very popular. Research efforts are directed towards 
breeding for fresh jasmine flowers with high yield of lower buds spread over many months of the year, long and soft corolla tube, bolder buds and better keeping quality (Table 2). The development of new variety of crop like New Guinea impatiens which is a novel innovative form, the wave petunia, a new use of existing crops (Chin and Tay, 2007; Halevy, 2000) are very successful commercially.

\section{Status of global ornamental germplasm}

The ornamental genetic resources have been assembled in a number of important collections around the world. The US National Plant Germplasm System (NPGS) is maintaining more than 450,000 accessions are mainly of food, fiber and industrial crops and only about 3,000 accessions are herbaceous ornamental plants. There is a critical need for a repository to take on this important task. The establishment of the new NPGS Ornamental Plant Germplasm Center (OPGC) at the Ohio State University (OSU) marked the beginning of this effort for the first time in the world. Approximately 3,200 accessions of 200 genera of herbacieous ornamental germplasm are maintained by OPGC. Some important commercial ornamental plants germplasm have been listed in the Table 3 . The major focus of this paper is on the diverse ornamental germplasm available at the different global portals and genebanks.
Despite the fact of availability of diverse ornamental genetic resources, majority of the collections are conserved in European countries. The EURISCO database (http://eurisco. ecpgr.org), brings data together from collections held by 51 organizations across Europe. EURISCO is based on a European network of ex situ National Inventories and makes these data accessible around the world.

For ornamental crops, the major contributors are collections held in the UK, Spain, Russia and Italy. The ornamental collection in the germplasm resources information network (GRIN) database of the U.S. Department of Agriculture-Agricultural Research Service (USDA-ARS) (http:// www.arsgrin.gov/npgs) is derived from germplasm from 74 countries around the world. GRIN is a web server providing information on plants, animals and microbes maintained by the USDA-ARS. The great majority of the accessions are held by the USDA Plant Introduction Stations at the University of Georgia and Washington State University. The genetic resources collections maintained at national genebank is an enormous biological reserve from accessions, for direct obtaining of a valuable potential sources of important promising traits for plant breeding work (Koeva et al., 2002).

Fig.1 Major commercial flowers cultivation in India (2015-16)

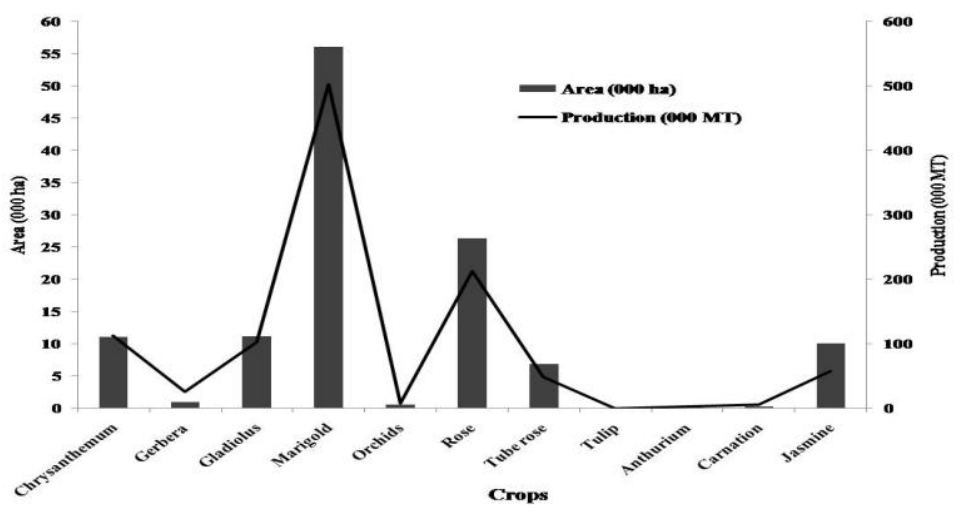


Fig.2 County wise import of commercial flowers in India (2015-16)

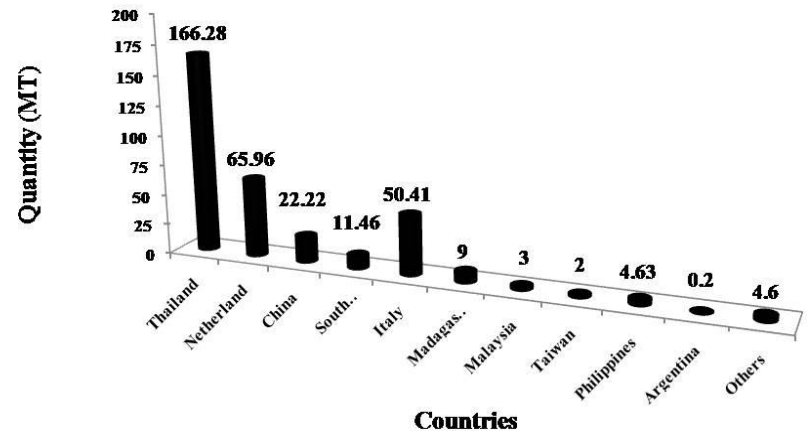

Fig.3 Status of introduced germplasm from 1982-2015

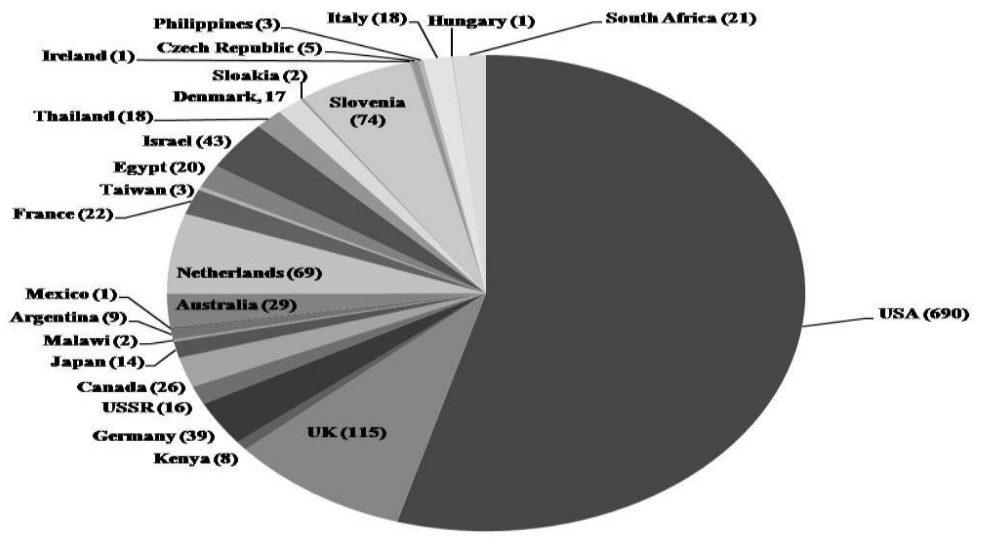

Fig.4 Trend of introduced germplasm from 1982-2015

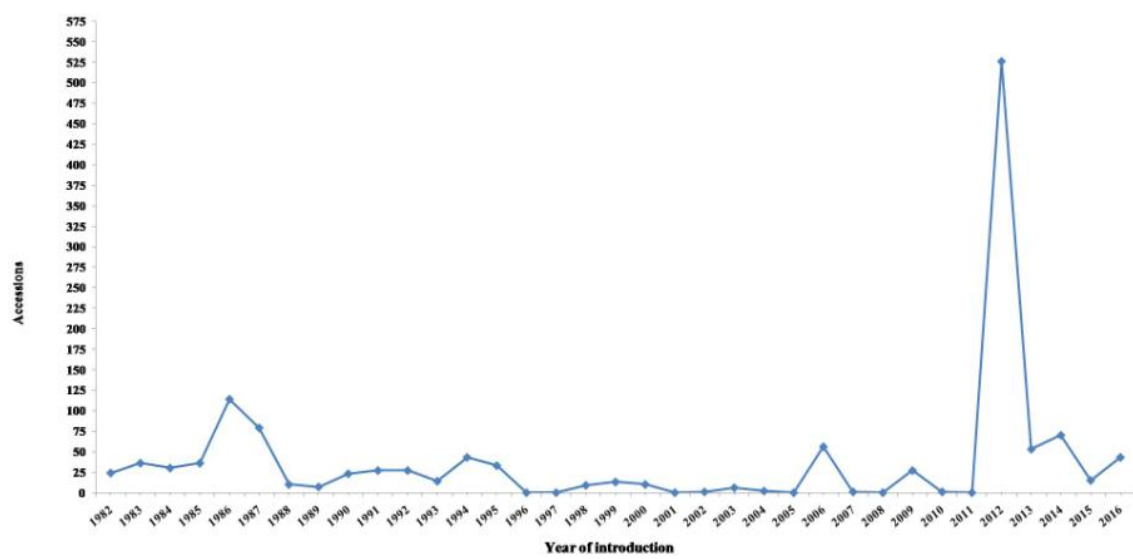


Table.1 Important registered ornamental germplasm

\begin{tabular}{|c|c|c|c|}
\hline Species & Accession & Pedigree & Promising trait \\
\hline $\begin{array}{l}\text { Rosa multiflora, } R \text {. alba, } \\
\text { R.brunonii, R. cathayensis }\end{array}$ & $\begin{array}{l}\text { IC549905, } \\
\text { IC549906, } \\
\text { IC549907, } \\
\text { IC549908 }\end{array}$ & - & Suitable strain for root stock \\
\hline R. indica & IC567489 & Clonal selection from $R$. indica & Ideal rootstock resistant to powdery mildew \\
\hline R. multiflora & IC567490 & Resistance identified in Nishkant & Ideal rootstock resistant to powdery mildew \\
\hline \multirow[t]{3}{*}{ R. hybrida } & IC0584135 & Bud Sport of R72 & $\begin{array}{l}\text { Shining foliage, unique bicolor consisting } \\
\text { vermillion red shading towards orient pink }\end{array}$ \\
\hline & IC0584136 & $\begin{array}{l}\text { Mutant of variety Dr. GS } \\
\text { Randhawa }\end{array}$ & $\begin{array}{l}\text { Less thorns, straight stalk, light pink } \\
\text { flowers with pointed bud }\end{array}$ \\
\hline & IC0574579 & Half sib progeny of Red Chief & Fragrant and tolerance to thrips \\
\hline \multirow[t]{4}{*}{ Gerbera jamesonii } & IC556977 & $\begin{array}{l}\text { Gerbera jamesonii (GJ4) x open } \\
\text { pollinated lines of Gerbera } \\
\text { jamesonii }\end{array}$ & Floriferous and double type \\
\hline & IC556978 & $\begin{array}{l}\text { Gerbera jamesonii (GJ4) x open } \\
\text { pollinated lines of Gerbera } \\
\text { jamesonii }\end{array}$ & Floriferous and good for open cultivation \\
\hline & IC0613966 & $\begin{array}{l}\text { CSIR-IHBT-Gr-1 } \quad x \quad \text { CSIR- } \\
\text { IHBT-Gr-7 }\end{array}$ & Double flower, medium size and white \\
\hline & IC0613967 & $\begin{array}{l}\text { CSIR-IHBT-Gr-2 } \quad x \quad \text { CSIR- } \\
\text { IHBT-Gr-3 }\end{array}$ & $\begin{array}{l}\text { Double flower shape, standard size with } \\
\text { yellow orange flower }\end{array}$ \\
\hline Jasminum ritchiei & IC553287 & Natural mutant & Variegated leaves \\
\hline Anthurium ornatum & IC556922 & Selection & $\begin{array}{l}\text { Emits fragrance during stigma receptivity, } \\
\text { easy to grow }\end{array}$ \\
\hline \multirow[t]{3}{*}{ Dianthus sp. } & IC561245 & D. caryophyllus $\mathrm{x}$ D. chinensis & $\begin{array}{l}\text { Inter specific hybrid with mass bloom } \\
\text { effect, good spray type }\end{array}$ \\
\hline & IC548347 & D. caryophyllus $\times$ D. chinensis & Micro-carnation genotype \\
\hline & IC561244 & D. chinesis $\mathrm{x}$ D. caryophyllus & Inter specific hybrid, good for potted plant \\
\hline \multirow[t]{4}{*}{ Callistephuschinensis } & IC0610420 & $\begin{array}{l}\text { Selection from OP seeds of line } \\
\text { no. } 173\end{array}$ & Early and high flowering \\
\hline & IC0610421 & $\begin{array}{l}\text { Selection from self seeds of line } \\
\text { no. } 15\end{array}$ & Early and high flowering \\
\hline & IC0610422 & $\begin{array}{l}\text { An advanced pedigree selection } \\
\text { of the cross local Pink x AST- } 2\end{array}$ & Violet, flower type: Pompon. \\
\hline & IC0610423 & $\begin{array}{l}\text { An advanced pedigree selection } \\
\text { (local Pink x AST-2) }\end{array}$ & $\begin{array}{l}\text { Creamy white, Powder puf type and } \\
\text { resistant to rootknot nematode }\end{array}$ \\
\hline \multirow[t]{4}{*}{ Gladiolus spp } & IC296733 & Green Wood peeker x Oscar & $\begin{array}{l}\text { Capsicum red flowers, lip petals chartreuse } \\
\text { yellow petals ruffled. }\end{array}$ \\
\hline & IC296774 & Vink's Glory x Eurovision & $\begin{array}{l}\text { Brick red petals having dresden yellow on } \\
\text { lip petals nicely ruffled. }\end{array}$ \\
\hline & IC296775 & Snow princess x Her Majesty & $\begin{array}{l}\text { Hybrid, with white petals having deep } \\
\text { purple violet edges }\end{array}$ \\
\hline & IC296776 & Snow princess x Her Majesty & $\begin{array}{l}\text { Reddish purple petals and dark reddish } \\
\text { purple blotches on the edges of both sides } \\
\text { of petal, lip with white stripes magenta petal }\end{array}$ \\
\hline \multirow[t]{3}{*}{ G.grandiflorus Andrews } & IC0584125 & Snow princess x Her Majesty & $\begin{array}{l}\text { Purple-violet having red-purple margin with } \\
\text { yellow-green blotch }\end{array}$ \\
\hline & IC0584126 & Green bay x Gold Medal-412 & Yellow lower lip with Red blotch \\
\hline & IC0584127 & Water melon Pink x Aarti & $\begin{array}{l}\text { Red floret having red margin and white line } \\
\text { on tepals with yellow blotch and resistant to } \\
\text { Fusarium wilt }\end{array}$ \\
\hline G. hybridus Hor & IC0611879 & $\begin{array}{l}\text { A cross between P-16-1 and } \\
\text { Eurovision }\end{array}$ & $\begin{array}{l}\text { Early blooming ( } 76-80 \mathrm{DAP}) \text { and red florets } \\
\text { with dark red stripes on inner two tepals, } \\
\text { and also red spots on outer throat, each } \\
\text { mother corm produces more than } 2.00\end{array}$ \\
\hline
\end{tabular}




\begin{tabular}{|c|c|c|c|}
\hline & & & corms. \\
\hline G. hybridus Hor & IC0611878 & $\begin{array}{l}\text { A selection among the open } \\
\text { pollinated seedlings of the } \\
\text { variety "Melody" }\end{array}$ & $\begin{array}{l}\text { Very early blooming ( } 74 \text { DAP), red florets } \\
\text { with two red spots on two central tepals. } \\
\text { Corm multiplications rate is higher and } \\
\text { produces more than } 2.00 \text { corms from each } \\
\text { mother corm }\end{array}$ \\
\hline Dendrobium hybrid & IC0574581 & D. emma white x D. pompadour & $\begin{array}{l}\text { Phalaenopsis type, broad and flat petals, } \\
\text { purple and big size flowers }\end{array}$ \\
\hline $\begin{array}{l}\text { Red Vanda (Renanthera } \\
\text { imschootiana) }\end{array}$ & IC0566525 & Collection from NE region & $\begin{array}{l}\text { Red flower, open broad sepals; endemic to } \\
\text { NE region }\end{array}$ \\
\hline Dendranthema grandiflora & $\begin{array}{l}\text { IC0568708 } \\
\text { IC0568709 }\end{array}$ & Selection from Punjab Gold & $\begin{array}{l}\text { Early and off-season flowering, suitable for } \\
\text { pot and garden use }\end{array}$ \\
\hline $\begin{array}{l}\text { Crossandra } \\
\text { infundibuliformis }\end{array}$ & IC567647 & - & High yield, triploid \\
\hline C.undulaefolia & IC560416 & Local x Laxmi crossandra & Bigger flower and higher yield \\
\hline C.undulaefolia & IC560417 & Local yellow x Delhi crossandra & Golden yellow and bigger size \\
\hline
\end{tabular}

IHBT: CSIR-Institute of Himalayan Bioresource Technology; NRC: National Research Centre for Orchids; TBGRI: Tropical Botanic Garden and Research Institute; DAP: Days after planting

\section{Table.2 Availability of major ornamental varieties in India}

\begin{tabular}{|c|c|c|}
\hline Crop & Varieties & Source \\
\hline Jasmine & $\begin{array}{l}\text { Parimullai, CO 1, CO 2, CO 1(Pitchi), Arka Surabhi (Pink pin), Gundumalli, } \\
\text { Ramban and Madanban, Double Mogra }\end{array}$ & $\begin{array}{lc}\text { TNAU, Coimbatore, } & \text { IIHR, } \\
\text { Bengaluru, IARI, New Delhi } & \end{array}$ \\
\hline $\begin{array}{l}\text { Chrysanthem } \\
\text { um }\end{array}$ & $\begin{array}{l}\text { Ajina Purple,Snowball, Potomac, M-24, Agnishikha, Batik, Harvest Home, } \\
\text { Gypsy Queen, Navneet Yellow, Gamit, Nanako, Gauri, Rosa, Shabnam, } \\
\text { Taruni, Pournima, Indira, Arka Pink Star, Nilima, Pusa Kesari, Pusa Sona, } \\
\text { Pusa Anmol, Pusa Centenary, Pusa arunodaya,,Pusa chitraksha, Pusa aditya, } \\
\text { Co-1, MDU-1, Shanti, Vasanti, Baggi }\end{array}$ & $\begin{array}{l}\text { NBRI, Lucknow, IIHR, Bengaluru, } \\
\text { IARI, New Delhi, TNAU, } \\
\text { Coimbatore, PAU }\end{array}$ \\
\hline Gladiolus & $\begin{array}{l}\text { Archana, Basant Bhar, Gazel, Jwala, Manhar, Manisha, Manmohan, Mohini, } \\
\text { Mukta, Pitambar, Smita, Triloki, Aldebaran, Friendship, Aarti, Apsara, } \\
\text { Meera, Poonam, Sapna, Shobha, grock, Jacksonville Gold, White Goddess, } \\
\text { Pusa Manmohak, Pusa Vidushi, Pusa Kiran, Pusa Shubam, Pusa Srijana, Pusa } \\
\text { Unnati, Pusa vidushi, KKL-1, A.Amar, A.Gold, A.Naveen, Kum Kum, Pusa } \\
\text { Red Valentine }\end{array}$ & $\begin{array}{l}\text { NBRI, Lucknow, IIHR, Bengaluru, } \\
\text { IARI, New Delhi, TNAU, } \\
\text { Coimbatore }\end{array}$ \\
\hline Marigold & $\begin{array}{l}\text { Atlantis Mixed F1, Crackerjack, Discovery Mixed F1, Galore Mixed F1, } \\
\text { Gold Coin Mixed, Jubilee Mixed F1, Orange Galore F1, Papaya Crush, } \\
\text { Vanilla F } F_{1} \text { Disco Mix Large, Hero Mix, Red Brocade, Safari Mix, Pusa arpita, } \\
\text { Pusa Narangi Gainda, Pusa basanti gainda, pusa bihar, MDU-1 }\end{array}$ & $\begin{array}{l}\text { IARI, New Delhi, TNAU, } \\
\text { Coimbatore }\end{array}$ \\
\hline Tuberose & $\begin{array}{l}\text { Rajat Rekha, Shringar, Single Mexican, Svarna Rekha, Suvasini, Vaibhav, } \\
\text { Arka Nirantara }\end{array}$ & IIHR, Bengaluru \\
\hline Bougainvillea & $\begin{array}{l}\text { Archana, Begum Sikander, Chitra, Dr.B.P.Pal, Los Banos Variegata, Los } \\
\text { Banos Variegata Mahara Variegata, Mahara Variegata abnormal leaves, } \\
\text { Manohar Chandra Variegata, Mary Palmer Special, Nirmal, Pallavi, } \\
\text { Parthasarthy, Spectabilis Variegata, Surekha, Wajid Ali Shah, Vishaka, } \\
\text { Spring Festival, Stanza, Summer time, Sonnet }\end{array}$ & NBRI, Lucknow, IARI \\
\hline Orchids & $\begin{array}{l}\text { Cymbidium 'B. S. Basnet', Aranda 'Kunga Gyatso' and Dendrobium } \\
\text { 'V.Nagaraju }\end{array}$ & NRC Orchids \\
\hline China aster & Kaminini, Violet cushion & IIHR, Bengaluru \\
\hline Crossandra & Arka ambara, A.Kanaka & IIHR, Bengaluru \\
\hline Gerbera & Arka Krishika, YCD-1, YCD-2 & $\begin{array}{l}\text { IIHR, Bengaluru, } \\
\text { Coimbatore }\end{array}$ \\
\hline Rose & $\begin{array}{l}\text { Arka Parimal, Delhi Princess, Bhabha, Sir C V Raman, Dr M S Randhawa, } \\
\text { Mrs K B Sharma and Uma Rao, Mrinalini, Jawahar, Dr B P Pal, } \\
\text { Raktagandha, Raja of Nalagarh, Tata Centanary, Priyadarshini, (HT), } \\
\text { Himangini, Prema, Sadabahar, Kiran, Chandrama, Neelambari, Mohini, Dr. } \\
\text { G.S. Randhawa (Floribunda). Varieties, Raktagandha and Arjun }\end{array}$ & IIHR, Bengaluru, IARI \\
\hline
\end{tabular}


Table.3 Availability status of important global ornamental germplasm

\begin{tabular}{|l|l|c|c|c|}
\hline SN & \multicolumn{1}{|c|}{ Crop } & GENESYS & USDA-GRIN & ERISCO \\
\hline 1. & Anthuriums & 26 & - & 697 \\
\hline 2. & Antirrhinum & 881 & 25 & 111 \\
\hline 3. & Aster & 15 & 6 & 3 \\
\hline 4. & Bougainvillea & 9 & - & 11 \\
\hline 5. & Calanthe & 30 & 80 & 355 \\
\hline 6. & Calendula & 425 & 8 & 296 \\
\hline 7. & Chrysanthemum & 330 & 2 & 40 \\
\hline 8. & Cosmos & 62 & - & 3 \\
\hline 9. & Crossandra & 4 & 82 & 400 \\
\hline 10. & Dianthus & 451 & - & 16 \\
\hline 11. & Gerbera & 18 & - & 379 \\
\hline 12. & Gladiolus & 369 & 22 & 103 \\
\hline 13. & Gypsophila & 143 & 24 & 932 \\
\hline 14. & Iris & 974 & 1 & 50 \\
\hline 15. & Jasmine & 44 & - & 102 \\
\hline 16. & Lilium & 215 & 43 & 382 \\
\hline 17. & Marigold & 530 & - & 8 \\
\hline 18. & Nymphaea & 10 & 1 & 183 \\
\hline 19. & Orchids & 190 & 1 & 74 \\
\hline 20. & Peony & 79 & 22 & 129 \\
\hline 21. & Petunia & 199 & - & 5 \\
\hline 22. & Bird of paradise & 4 & 61 & 3785 \\
\hline 23. & Rose & 1052 & - & 1 \\
\hline 24. & Tube rose & - & - & 532 \\
\hline 25. & Tulips & 490 & 6 & 250 \\
\hline 26. & Viola & 422 & 42 & $\mathbf{8 9 6 3}$ \\
\hline 27. & Zinnia & $\mathbf{6 9 7 4}$ & & \\
\hline & Total & & & \\
\hline & & $\mathbf{4 2 8}$ & & \\
\hline
\end{tabular}

Table.4 Priority Ornamental crops and its species for further introductions

\begin{tabular}{|c|c|c|c|}
\hline $\mathrm{SN}$ & Crop & Species & Source \\
\hline 1. & Anthuriums & $\begin{array}{l}\text { Anthurium bakeri, A.upalaense, A.sparreorum, A. } \\
\text { scherzerianum, A.sanctifidense, A.salvinii, A.pedatoradiatum, } \\
\text { A. obtusum, A.margaritaceum, A. magnificum, A.llewelynii, } \\
\text { A.kunthii, A.hookeri, A.harrisii, A.guatemalense, A.gracile, }\end{array}$ & $\begin{array}{l}\text { Subtropical Horticultural Research Unit, National } \\
\text { Germplasm Repository- Miami; } \\
\text { OPGC, Ohio State University }\end{array}$ \\
\hline 2. & Antirrhinum & $\begin{array}{l}\text { Antirrhinum charidemi, A. latifolium, A. nuttallianum, A. } \\
\text { molle, A. litigiosum, A. grosii, A. austral, A. valentinum, A. } \\
\text { microphyllum }\end{array}$ & Botanic Garden, University of Copenhagen, Denmark \\
\hline \multirow[t]{2}{*}{3.} & Bird of paradise & Strelitzia reginae,S. nicolai, S. juncea, S. augusta & Royal botanical garden \\
\hline & Bougainvillea & Bougainvillea glabra, B. spectabilis & $\begin{array}{l}\text { Station Expérimentale, Institut Technique } \\
\text { d'Arboriculture Fruitière et de la Vigne, Algeria }\end{array}$ \\
\hline 5. & Calanthe & $\begin{array}{l}\text { Calanthe arisanensis, } C \text {. triplicate, } C \text {. sylvatica, } C \text {. striata, } C \text {. } \\
\text { puberula, } \text { C.discolor, C. alpina }\end{array}$ & $\begin{array}{l}\text { Research Institute of Landscaping and Ornamental } \\
\text { Gardening, Czech Republic }\end{array}$ \\
\hline 6. & Chrysanthemum & $\begin{array}{l}\text { Chrysanthemum } x \text { hortorum, C. zawadskii, C. pacificum, } C \text {. } \\
\text { carinata, Chrysanthemum } x \text { spectabile, C. multicaulis, } C . \\
\text { lavandulifolium }\end{array}$ & $\begin{array}{l}\text { Institute of Genetics Academy of Sciences of } \\
\text { Moldova; Nikitskyi Botanical Gardens, Ukraine; } \\
\text { Botanical Garden, Institute of Plant Research, } \\
\text { Chinese Academy of Sciences; Saga University, } \\
\text { Japan }\end{array}$ \\
\hline 7. & Cosmos & $\begin{array}{l}\text { Cosmos caudatus, } C . \text { parviflorus, } \quad \text { C. diversifolius, } \quad \text { C. } \\
\text { atrosanguineus }\end{array}$ & $\begin{array}{l}\text { Herbagro BV, Netherlands; Agricultural Research } \\
\text { Station Suceava, Romania }\end{array}$ \\
\hline 8. & Crossandra & Crossandra puberula,C. longipes, C. albolineata & $\begin{array}{l}\text { Tropical Agricultural Research Station, Medagascar; } \\
\text { National Plant Genetic Resources Center, Tanzania }\end{array}$ \\
\hline 9. & Orchids & $\begin{array}{l}\text { Cymbidium bicolor, C. canaliculatum, C.suave, C. goeringii, } \\
\text { C. sanderae, C. suavissimum, C. rectum, C. pauwelsii x } \\
\text { tracyanum, C. kanran, C. floribundum, C. finlaysonianum, } \\
\text { Dendrobium rennellii, D. bigibbum, D. speciosum, D. } \\
\text { tetragonum, D. striolatum, D. pulchellum, D. polyanthum, D. } \\
\text { gracilicaule, D. wardianum, D. teretifolium, D. taurinum }\end{array}$ & $\begin{array}{l}\text { National Arboretum-Germplasm Unit, USDA, The } \\
\text { Botanical Garden Organization, Thailand }\end{array}$ \\
\hline
\end{tabular}




\begin{tabular}{|c|c|c|c|}
\hline 10. & Dianthus & $\begin{array}{l}\text { Dianthus versicolor, D. subacaulis, D. strictus, D. serrulatus, } \\
\text { D.orientalis, D.lusitanicus,D. arenarius, }\end{array}$ & $\begin{array}{l}\text { Botanical Garden of Plant Breeding and } \\
\text { Acclimatization Institute, Poland; PGRC, Germany; } \\
\text { Universidade do Porto, Portugal }\end{array}$ \\
\hline 11. & Gerbera & $\begin{array}{l}\text { Gerbera piloselloides, G. aurantiaca, G. wrightii, } G . \\
\text { viridiflora, G. linnaei, G. cordata, G. aristata,G. ambigua }\end{array}$ & $\begin{array}{l}\text { Genetic Resources Unit, Institute of Biological, } \\
\text { Environmental and Rural Sciences, Aberystwyth } \\
\text { University, UK }\end{array}$ \\
\hline 12. & Gladiolus &  & $\begin{array}{l}\text { Laboratory of Plants Gene Pool and Breeding, } \\
\text { Armenia; Czechoslovakia }\end{array}$ \\
\hline 13. & Gypsophila & $\begin{array}{l}\text { G. elegans, } G . \text { struthium, } G . \text { pilosa, } G . \text { oldhamiana, } G . \\
\text { trichotoma, G. tomentosa, G. ruscifolia, G. glomerata, } G . \\
\text { davurica, G. capillaries, G. bicolor, G. altissima, } G . \\
\text { acutifolia }\end{array}$ & $\begin{array}{l}\text { NBG, Latvia; Botanical Garden and Rhododendron } \\
\text { Park, Germany }\end{array}$ \\
\hline 14. & Iris & $\begin{array}{l}\text { Iris missouriensis, I. domestica, I. lacteal, I. spuria, I. pumila, } \\
\text { I. germanica, I. ensata, I. ruthenica, }\end{array}$ & $\begin{array}{l}\text { Institute of Hop Research and Brewery, Slovinia; } \\
\text { Universidade Lisboa, Portugal; Botanical Garden, } \\
\text { University of Oslo, Norway }\end{array}$ \\
\hline 15. & Jasmine & $\begin{array}{l}\text { J. stenolobum, J. puberulum, J. pauciflorum, J. parkeri, J. } \\
\text { odoratum, J. octocuspe, J. multipartitum, J. molle }\end{array}$ & $\begin{array}{l}\text { Jardin botanique de Bordeaux, France; Hortus } \\
\text { Botanicus, Instituto de Botânica 'Dr Gonçalo } \\
\text { Sampaio', Universidade do Porto, Portugal ; Royal } \\
\text { Botanic Gardens Sydney }\end{array}$ \\
\hline 16. & lilium & $\begin{array}{l}\text { Lilium pumilum, } L . \text { bulbiferum, } L . \text { philadelphicum, } L . \\
\text { pensylvanicum, } L . \text { distichum, } L . \text { michiganense } L . \text { pyrenaicum, } \\
L . \text { pardalinum, L. iridollae, } L . \text { sargentiae }\end{array}$ & $\begin{array}{l}\text { PGRC, Germany; Centre for Genetic Resources, the } \\
\text { Netherlands Plant Research International; Research } \\
\text { Institute of Pomology and Floriculture, Poland }\end{array}$ \\
\hline 17. & Marigold & $\begin{array}{l}\text { Tagetes coronopifolia, T. lucida, T. signata, T. micrantha, } T \text {. } \\
\text { lunulata,T. subulata, agetes parryi, T. nana }\end{array}$ & $\begin{array}{l}\text { Institute for Plant Genetic Resources 'K.Malkov', } \\
\text { Bulgaria; Institute of Genetics Academy of Sciences } \\
\text { of Moldova, Republic of Moldova; Herbagro BV, } \\
\text { Netherlands; Civico Orto Botanico di Trieste, Italy }\end{array}$ \\
\hline 18. & Nymphaea & $\begin{array}{l}\text { Nymphaea violacea, } N . \text { thermarum, N.nouchalii, N. maculata, } \\
\text { N. hastifolia, } N . \text { georginae, } N . \text { alexii } \\
\text { N. alba }\end{array}$ & $\begin{array}{l}\text { Gembloux agro-biotech, Université de Liège, } \\
\text { département des Sciences agronomiques, } \\
\text { Phytotechnie tropicale et Horticulture, Belgium }\end{array}$ \\
\hline 19. & Paphiopedilum & 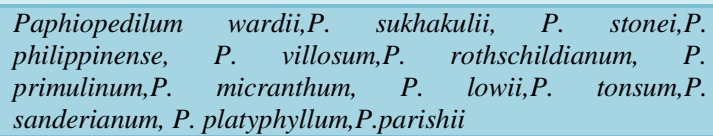 & Royal Botanic Gardens, Kew \\
\hline 20. & Peony & $\begin{array}{l}\text { Paeonia tenuifolia, } P . \text { mascula, } P . \text { cambessedesii, } P . \\
\text { suffruticosa, } P . \text { broteroi,P.caucasica, } P . \text { mlokosewitschii, } P \text {. } \\
\text { lactiflora, } P . \text { coriacea, P. peregrine, } P . \text { lutea, } P . \text { emodi, } P \text {. } \\
\text { corsica, } P . \text { broteri, P.anomala, } P . \text { 'anne rosse',P. } \\
\text { wittmanniana }\end{array}$ & Botanical Garden, University of Oslo \\
\hline 21. & Petunia & $\begin{array}{l}\text { Petunia atkinsiana, } P . \text { nyctaginiflora, } P . \text { integrifolia, } P . \\
\text { exserta, P. parviflora }\end{array}$ & Royal Botanic Gardens, Kew \\
\hline 22. & Pot marigold & $\begin{array}{l}\text { Calendula suffruticosa, C. incana, C. lanzae, C. percica, C. } \\
\text { tripterocarpa, C. meuselii, C. eckerleinii, C. pluvialis, } C \text {. } \\
\text { palaestina, }\end{array}$ & $\begin{array}{l}\text { PGRC, Germany; Institute of Hop Research and } \\
\text { Brewery, Slovenia; Orto Botanico dell' Università di } \\
\text { Palermo, Italy }\end{array}$ \\
\hline 23. & Rose & Rosa davurica, $R$. arvensis, $R$. palustris & $\begin{array}{l}\text { Nikitskyi Botanical Gardens, Ukraine; Russian } \\
\text { Academy of Sciences, Russia; Royal Botanic } \\
\text { Gardens, Kew; Centro Nacional de Recursos } \\
\text { Fitogenéticos, Spain; Institute of Botany and } \\
\text { Botanical Garden, Vienna }\end{array}$ \\
\hline 24. & Tulips & $\begin{array}{l}\text { Tulipa hybrida hort., T. greigii, T. fosteriana, T. sylvestris, T. } \\
\text { orphanidea, T. biflora, T. turkestanica, T. praestans, T. } \\
\text { bifloriformis, T. undulatifolia, T. ostrowskiana, T. Montana, } \\
\text { T. borszczowii, T. urumiensis, T. tschimganica }\end{array}$ & $\begin{array}{l}\text { Bohemia Bulbs, Breeding Station, Czech Republic; } \\
\text { Research Institute of Landscaping and Ornamental } \\
\text { Gardening, Czech Republic; Research Institute of } \\
\text { Pomology and Floriculture, Poland }\end{array}$ \\
\hline 25. & Vanda & Vanda tricolor, V. cristata, V. tessellate, V. denisoniana & Royal Botanical Garden, Nepal \\
\hline 26. & Viola & $\begin{array}{l}\text { Viola palmata, V.striata, V.sagittata, V.blanda, V.arvensis, } \\
\text { V.lutea, V.riviniana, V.pubescens, V.hastate, V.rupestris, } \\
\text { V.langsdorffii, V.hederacea, V.adunca, V. walteri }\end{array}$ & OPGC, Ohio State University \\
\hline
\end{tabular}

PGRC: Plant Genetic Resource Collection; NBG:National Botanical Garden; OPGR:Ornamental Plant Germplasm Centre 
Priority ornamental crops and its species for further introductions

The major priority area for the need of further introduction of ornamental germplasm (Table 4) are raising commercial flowers prices, export revenue, farmers income, employment generation. The strategy of the present analysis based on the relevant reports and different international institutes. Botanical Gardens play an important role in the conservation and the utilization of ornamental plants genetic resources (Bretting, 2007; Oldfield, 2011; Okhawa, 2003; Primack, 2000; Volk and Richards, 2008, Sharrock, 2006).

The global demand of ornamental crops is definitely going to increase in coming years and it is clear that innovative production and marketing efforts are needed. Initiation of cultivation in a new production area with a diverse climate, research needs to be focused primarily on the development of new commercial varieties. Searching of new sources of genes from the already collected and conserved germplasm is greatly needed with reference to the utilization of germplasm in breeding programmes. The genotypes developed with significant promising traits from the valuable conserved germplasm plays a major role in the varietal development. The diverse genetic resources are the essence of our breeding programs, and also more demand for tropical flowering plants. Some important species of bromeliad, canna, abutilon, African violet, amaryllis etc. are more suitable for tropical climate. It is essential to widen the germplasm base by introducing lesser known ornamentals as crop development and adaptation is a continuous effort and needs a skilled research agenda. With the fast changing global scenario and increasing demands for income and employment generation, flower production has come up in a big way under diversified horticulture. Although the collection of major ornamental crops is already available to users there are still possibilities to conserve and utilize lesser known new crops to further enhance the breeding programme of ornamental crops.

\section{Acknowledgement}

We are sincerely acknowledging the Director of ICAR-NBPGR for the continuous support of present work.

\section{References}

Anitha Pedapati, Vandana Tyagi, Anil K Singh, Nidhi Verma, Yadav S K, Singh S P, Surender Singh and Pratibha Brahmi. 2014. Spices and Condiments: Status of Genetic Resources and Setting Priorities for Introduction in India. Environment \& Ecology 32 (3A): 1051-1056.

Boyle, T H. 1991. The genetic resources of Latin America's herbaceous ornamental crops-vital to commercial floriculture. Diversity. 7: 50-51.

Bretting, P.K. 2007. The U.S. National Plant Germplasrn System in an era of shifting international nornis for germplasm exchange. Acta Hort. 760: 55-60.

Chin, H. F and D. Tay 2007. Conservation and Utilization of Ornamental Germplasm. Acta Horti. 760: 581-587.

Flavia Barbosa Silva Botelho, Cinthia Souza Rodrigues and Adriano TeodoroBruzi 2015. Ornamental plant breeding: Ornamental horticulture. 21(1): 9-16.

Heywood, V 2003. Conservation and Sustainable Use of Wild Species as sources of New Ornamentals. Acta Hort.598: 42-53.

Halevy, A,H 2000., Introduction of native Israeli plants as new cut flowers. In: IV International symposium on new 
floricultural crops. Acta Horticulturae. 541.

Indian Horticulture Database 2015. National Horticulture Board, Ministry of Agriculture, Government of India.

India Stat Horticultural Statastics 2017. Available from http://indiastat.com. Accessed in January.

Inventory of Registered Crop Germplasm 2016. www.nbpgr.ernet.in. Accessed in December.

Jaenicke, H. 2013. Germplasm conservation of ornamental plants - what we can learn from agriculture. Acta Hort.977: 19-28.

Koeva, R., S. Angelova and Guteva, Y. 2002. Plant Genetic Resources and Their Biological Potential Integrated to the Agricultural and Ecological Systems. Biotechnology \& Biotechnological Equipment. 16 (2): 26-35.

Kumar, R., T.N. Saha, P.N. Kumar and Kumar, G. 2012. Background Information 2006-11. All India Coordinated Research Project on Floriculture. Directorate of Floricultural Research, ICAR., 184.

NBRI Research achievements. 2017. http://www.nbri.res.in/.

Oldfield, S, 2011. Conserving wild plants for food and medicines- the work of Botanic gardens. Acta Hort. 918: 3542.

Okhawa, K 2002. Flower industry in northeast asia: development and introduction of new crops. p. In: IV
International Symposium on New Floricultural Crops. Acta Hort. 541: 125-133.

Pedapati Anitha, Vandana Tyagi, Yadav, S.K. Pratibha Brahmi and Murugesan, P. 2013. Present status and future priorities for introduction of oil palm in India. The Ecoscan 7 (3\&4): 139144.

Primack, R.B, A.J. Miller-Rushing Tansley 2009. The role of botanical gardens in climate change research. New Phytol. 182: 303-313.

Sharrock, S 2006. The role of botanic gardens in the conservation of crop wild relatives. BGjournal 3(1):16-19.

Yadav, S. K., Nidhi Verma, Vandana Tyagi, Anitha, P. Singh, S.P. Ranga, S.S. Binda, P.C. and Pratibha Brahmi. 2014. Exchange of plant genetic resources: Prospects in India. Indian Journal of Agricultural Sciences. 84(5): 616-23.

Tay, D. 2007. Herbaceous Ornamental Plant Germplasm Conservation and Use. In: Anderson N.O. (eds) Flower Breeding and Genetics. Springer, Dordrecht. 113-117.

Volk, G.M., and Richards, C.M. 2008. Availability of genotypic data for USDA. ARS National Plant Germplasm System accessions using the Genetic Resources Information Network (GRIN) database. HortScience. 43:1365-1366.

\section{How to cite this article:}

Anitha Pedapati, Satish Kumar Yadav, Vandana Tyagi, S.P. Singh, S.S. Ranga, P.C. Binda and Pratibha Brahmi. 2018. Ornamental Germplasm: Potential New Resources for Floriculture Industry. Int.J.Curr.Microbiol.App.Sci. 7(12): 1731-1742. doi: https://doi.org/10.20546/ijcmas.2018.712.201 